\title{
Advanced Glycation Endproducts Interacting with Their Endothelial Receptor Induce Expression of Vascular Cell Adhesion Molecule-1 (VCAM-1) in Cultured Human Endothelial Cells and in Mice
}

\author{
A Potential Mechanism for the Accelerated Vasculopathy of Diabetes
} Ann Marie Schmidt, Osamu Hori, Jing Xian Chen, Jian Feng Li, Jill Crandall, Jinghua Zhang, Rong Cao, Shi Du Yan,
Jerold Brett, and David Stern

Departments of Medicine and Physiology, Columbia University-College of Physicians and Surgeons, New York 10032

\begin{abstract}
Vascular cell adhesion molecule-1 (VCAM-1), an inducible cell-cell recognition protein on the endothelial cell surface (EC), has been associated with early stages of atherosclerosis. In view of the accelerated vascular disease observed in patients with diabetes, and the enhanced expression of VCAM-1 in diabetic rabbits, we examined whether irreversible advanced glycation endproducts (AGEs), could mediate VCAM-1 expression by interacting with their endothelial cell receptor (receptor for AGE, RAGE). Exposure of cultured human ECs to AGEs induced expression of VCAM1 , increased adhesivity of the monolayer for Molt- 4 cells, and was associated with increased levels of VCAM-1 transcripts. The inhibitory effect of anti-RAGE IgG, a truncated form of the receptor (soluble RAGE) or $\boldsymbol{N}$-acetylcysteine on VCAM-1 expression indicated that AGE-RAGE-induced oxidant stress was central to VCAM-1 induction. Electrophoretic mobility shift assays on nuclear extracts from AGE-treated ECs showed induction of specific DNA binding activity for NF-kB in the VCAM-1 promoter, which was blocked by anti-RAGE IgG or $\boldsymbol{N}$-acetylcysteine. Soluble VCAM-1 antigen was elevated in human diabetic plasma. These data are consistent with the hypothesis that AGERAGE interaction induces expression of VCAM-1 which can prime diabetic vasculature for enhanced interaction with circulating monocytes. (J. Clin. Invest. 1995. 96:1395-1403.) Key words: hyperglycemia $\bullet$ atherosclerosis • adhesion molecule $\bullet$ endothelium $\bullet$ oxidation
\end{abstract}

\section{Introduction}

Accelerated atherosclerosis and microvascular disease are the major vascular complications of diabetes, and constitute the

Address correspondence to Dr. Ann Marie Schmidt, Department of Medicine, $P$ \& S 11-518, Columbia University-College of Physicians and Surgeons, 630 West 168th Street, New York, New York 10032. Phone: 212-305-1615; FAX: 212-305-5337. J. Crandall's present address is Department of Medicine, Joslin Center for Diabetes, St. Luke'sRoosevelt Hospital, New York, NY, 10019.

Received for publication 13 January 1995 and accepted in revised form 9 May 1995.

J. Clin. Invest.

(C) The American Society for Clinical Investigation, Inc.

0021-9738/95/09/1395/09 \$2.00

Volume 96, September 1995, 1395-1403 principal cause of morbidity and mortality in this ubiquitous disorder (1-2). Many underlying factors could contribute to this outcome, including abnormalities in plasma lipoproteins, blood pressure, and renal function. A final common pathway in the development of vascular pathology is the expression of inducible adhesion molecules rendering the vasculature a selective target for circulating peripheral blood cells. In this context, vascular cell adhesion molecule-1 (VCAM-1) ${ }^{1}$ is of particular interest as its expression has been linked to the early phase of experimental hypercholesterolemia-induced atherosclerosis (34 ), and enhanced vascular VCAM-1 expression has been demonstrated in the vasculature of alloxan-treated diabetic rabbits (5) as well as in human atherosclerotic lesions (6).

To identify a sustained stimulus for enhanced expression of VCAM-1 in diabetes, we have considered a potentially etiologic role for advanced glycation endproducts (AGEs). Exposure of proteins and lipids to aldoses results in nonenzymatic glycation; initially forming reversible early glycation products, Schiff bases, and Amadori products (7), which, after complex molecular rearrangements, become irreversible AGEs (8-10). The latter constitute a class of heterogeneous structures of yellowbrown color, characteristic fluorescence, which form crosslinks, generate reactive oxygen intermediates (ROIs), and interact with particular cellular receptors $(8-11)$. The endothelial receptor for AGEs, termed RAGE, is a newly identified member of the immunoglobulin superfamily of cell surface molecules and has been shown to mediate interactions with these glycated proteins in vitro and in vivo (11-14). RAGE is expressed both in normal (15) and diabetic vasculature (A. M. Schmidt and D. Stern, unpublished observations ).

Since AGEs are found in the plasma and accumulate in the vessel wall in diabetes, the potential role of interaction of AGEs with endothelial RAGE in induction of VCAM-1 expression was examined. Our data indicate that AGEs, either those prepared in vitro or isolated from patients with diabetes, led to VCAM-1 expression in cultured ECs by a mechanism involving AGE binding to RAGE likely as a consequence of induction of cellular oxidant stress and activation of the transcription factor NF-kB. Infusion of AGEs into mice also enhanced vascular VCAM-1 expression, and soluble VCAM-1 antigen was ele-

1. Abbreviations used in this paper: AGE, advanced glycation endproduct; EC, endothelial cell; EMSA, electrophoretic mobility shift assay; GAPDH, glyceraldehyde phosphate dehydrogenase; MP, mononuclear phagocyte; NAC, N-acetylcysteine; RAGE, receptor for AGE; ROI, reactive oxygen intermediate; sRAGE, soluble RAGE; sVCAM-1, soluble VCAM-1; VCAM-1, Vascular Cell Adhesion Molecule-1; VLA-4, very late antigen 4. 
vated in plasma of patients with diabetes, suggesting increased VCAM-1 production. These data support the concept of a role for AGEs in enhanced expression of VCAM-1 in diabetes, and suggest that this could provide a mechanism for targeting mononuclear phagocytes (MPs) to diabetic vasculature.

\section{Methods}

Endothelial cell culture and RAGE blocking reagents. Human ECs were prepared from umbilical cords, grown in culture as described $(16,17)$, and experiments utilized confluent cultures (passages 1-3) grown in Medium 199 supplemented with fetal bovine serum (15\%; Gemini, Calabasas, CA), human serum (5\%; Gemini), endothelial cell growth supplement (Boehringer Mannheim, Indianapolis, IN), heparin $(90 \mu \mathrm{g} /$ $\mathrm{ml}$; Sigma Chemical Co., St. Louis, MO) and antibiotics. In most experiments, human umbilical vein endothelial cells (ECs) were used, but where specifically indicated, certain experiments were performed with human aortic endothelial cells (Clonetics, San Diego, CA). Confluent cultures of human aortic endothelial cells were used for experiments at passages 4-6. RAGE is present on the surface of both human umbilical vein and human aortic endothelial cells by immunohistochemistry using previously published methods (15, data not shown). Blockade of EC RAGE used soluble(s) bovine RAGE and monospecific antibody to sRAGE. Bovine RAGE was purified to homogeneity from bovine lung acetone powder (Sigma Chemical Co.) by the methods previously described (12). This material represents the amino-terminal two-thirds of the molecule based on analysis of tryptic peptides and is called soluble RAGE or SRAGE. Purified bovine RAGE was used to immunize rabbits, according to previously described methods (18), IgG was purified by affinity chromatography with immobilized protein $\mathrm{A}$, and nonimmune rabbit IgG was similarly prepared. Immunoblotting studies showed that anti-RAGE IgG was monospecific; it bound only RAGE and binding was blocked completely by pre-adsorption with purified RAGE. $\mathrm{F}\left(\mathrm{ab}^{\prime}\right)_{2}$ was prepared from IgG with a kit from Pierce (Rockville, IL) according to the manufacturer's instructions. The final $\mathrm{F}\left(\mathrm{ab}^{\prime}\right)_{2}$, which was homogeneous on SDS PAGE, was then dialyzed extensively versus phosphate-buffered saline.

Preparation of glycated proteins and antibodies. Bovine serum albumin (fatty acid free; Sigma Chemical Co.) was glycated by incubation with glucose $(0.5 \mathrm{M})$ at $37^{\circ} \mathrm{C}$ for $4 \mathrm{wk}$. Glycated proteins were characterized based on fluorescence, binding to cultured ECs and to purified RAGE (18). SDS-PAGE showed a single major band corresponding to $\sim 69 \mathrm{kD}$, and the isoelectric point was largely unchanged (a shift of $<0.1-0.3 \mathrm{pH}$ units toward acidity was variably noted; characterization of these glycated albumin preparations has previously been described in detail [18]). Nonglycated albumin was treated identically as glycated albumin (i.e., incubation at $37^{\circ} \mathrm{C}$ for 4 wk) except that no glucose was present in the reaction mixture. AGEs were immunoisolated from diabetic serum using affinity-purified anti-AGE IgG, prepared and characterized as described previously $(18,19)$. This antibody selectively reacts with AGE-modified forms of proteins, but not native polypeptides, nor early glycation adducts, or other modifications (formylation, maleylation, acetylation, or copper oxidation ) (19). Anti-AGE IgG was immobilized on Affi-Gel 10 (BioRad, Hercules, CA) according to the manufacturer's instructions and diabetic serum was applied. The material that did not adhere to this column, defined as AGE-depleted serum, was subsequently negative for AGE-immunoreactive material as determined by AGE ELISA which used the above affinity-purified anti-AGE IgG $(18,19)$. After collecting the AGE-depleted material, the column was washed extensively with neutral buffer and eluted with high salt $(\mathrm{NaCl}$, $2 \mathrm{M}$ ) as described (18). Serum samples were obtained from the Medical and Endocrinology Clinics at Columbia-Presbyterian Medical Center or from normal individuals (ages 24-69 yr) after obtaining informed consent, according to a protocol approved by the Institutional Review Board

Assays for VCAM-1. AGE-induced modulation of endothelial VCAM-1 was studied by assessing binding of Molt- 4 cells to EC mono- layers, by ELISA for cell-associated VCAM-1 antigen and in EC supernatants, by electrophoretic mobility shift assay (EMSA), by Northern analysis, by nuclear run-on analysis, and by immunostaining following AGE albumin infusion into mice.

Molt-4-EC binding assays. Molt-4 EC binding assays were performed by the general method of Marui et al. (20). ECs, grown to confluence in $0.38 \mathrm{~cm}^{2}$ wells, were washed twice in Medium 199 containing fetal bovine serum (1\%) and then exposed to either AGE albumin or native albumin for the indicated time at $37^{\circ} \mathrm{C}$. Where indicated, ECs were pre-treated with one of the following: $N$-acetylcysteine (NAC; $30 \mathrm{mM}$ for $60 \mathrm{~min}$ ), cycloheximide ( $50 \mu \mathrm{g} / \mathrm{ml}$ for $60 \mathrm{~min}$ ), anti-RAGE $\mathrm{F}\left(\mathrm{ab}^{\prime}\right)_{2}(2 \mu \mathrm{g} / \mathrm{ml}$ for $3 \mathrm{~h})$, nonimmune $\mathrm{F}\left(\mathrm{ab}^{\prime}\right)_{2}(2 \mu \mathrm{g} / \mathrm{ml}$ for $3 \mathrm{~h})$, or anti-VCAM-1 $\mathrm{F}\left(\mathrm{ab}^{\prime}\right)_{2}(10 \mu \mathrm{g} / \mathrm{ml}$ or $0.1 \mu \mathrm{g} / \mathrm{ml}$ for $30 \mathrm{~min}) . \mathrm{F}\left(\mathrm{ab}^{\prime}\right)_{2}$ fragments prepared from murine monoclonal antibody to VCAM-1 (2G7) were generously provided by Dr. Walter Newman and Dawson Beall (Otsuka, America, Rockville, MD) (21). Purified recombinant tumor necrosis factor-alpha (generously provided by Knoll Pharmaceuticals, Whippany, $\mathrm{NJ}, 10^{8} \mathrm{U} / \mathrm{mg}$ ) was added to other EC cultures as a positive control (20). Molt-4 cells (purchased from American Type Cell Culture, Rockville, MD), which express very late antigen-4 (22), were grown in RPMI 1640 containing fetal bovine serum (10\%). Radiolabelling was accomplished by incubating Molt- 4 cells $\left(2 \times 10^{7}\right.$ cells $/$ $\mathrm{ml})$ for $16 \mathrm{~h}$ at $37^{\circ} \mathrm{C}$ in the above medium containing ${ }^{51} \mathrm{Cr}(0.2 \mathrm{mCi} / \mathrm{ml})$. Before the binding assay, nonincorporated radioactivity was removed by washing cells twice with Hanks balanced salt solution, and then resuspending them in RPMI containing fetal bovine serum (10\%) at 4 $\times 10^{6}$ cells $/ \mathrm{ml}$. Molt- 4 cells were incubated with ECs for $1 \mathrm{~h}$ at $37^{\circ} \mathrm{C}$, and nonadherent cells were removed by washing twice with Medium 199 containing fetal bovine serum (1\%), adherent cells were solubilized in SDS $(1 \%)$, and radioactivity was determined. Where indicated, results are expressed as percent above control compared with Molt-4 binding to ECs treated with native, nonglycated albumin (which was identical to findings with incubation buffer control alone).

ELISA. ELISA for human VCAM-1 was performed using a kit from British Bio-technology Products (Abingdon, Oxon, UK) according to the manufacturer's instructions. The limit of detection in this assay is $<2 \mathrm{ng} / \mathrm{ml}$. Where indicated, human umbilical vein endothelial cells (ECs) or human aortic endothelial cells were treated with the indicated reagents in Medium 199 containing fetal bovine serum (1\%). At the conclusion of the experiments, culture supernatants were collected and subjected to 10 -fold concentration using Centricon-10 membranes (Amicon, Beverly MA) and assayed for VCAM-1 antigen by placing equal volumes of concentrated supernatant per well. For assay of cellassociated VCAM-1 antigen or ICAM-1 antigen, cells were washed twice with phosphate-buffered saline, scraped into buffer containing tris $20 \mathrm{mM}$ ( pH 7.4), $\mathrm{NaCl}(0.1 \mathrm{M}), \mathrm{PMSF}(0.002 \mathrm{M})$ and octyl- $\beta$-glucoside $(1 \%)$ (Boehringer-Manheim, Indianapolis IN), rocked at $4^{\circ} \mathrm{C}$ for $4 \mathrm{~h}$, and then centrifuged at $11,000 \mathrm{~g}$ for $20 \mathrm{~min}$. The supernatant was collected and protein concentration determined using the Bradford reagent (Bio-Rad, Richmond, CA). For ELISA of cell lysates, $0.75 \mathrm{mg}$ of protein was added to each well. Where indicated, EC monolayers were pretreated with cycloheximide ( $50 \mu \mathrm{g} / \mathrm{ml}$ for $60 \mathrm{~min}$ ), anti-RAGE IgG $(30 \mu \mathrm{g} / \mathrm{ml}$ for $3 \mathrm{~h})$, nonimmune IgG $(30 \mu \mathrm{g} / \mathrm{ml}$ for $3 \mathrm{~h})$, or $N$ acetylcysteine ( $30 \mathrm{mM}$ for $60 \mathrm{~min}$ ). Determination of soluble ICAM1 used a commercially available ELISA according to the manufacturer's instructions (British Biotechnology Products, Abingdon, Oxon, UK). The limit of detection in this assay is $<2.5 \mathrm{ng} / \mathrm{ml}$. Where indicated, results are expressed as fold increase above control compared with elaboration of cellular or supernatant VCAM-1 antigen or ICAM-1 antigen from ECs treated with native, nonglycated albumin (which was identical to results obtained with incubation buffer control alone). Determination of plasma AGE levels was determined by ELISA according to previously published methods $(18,19)$.

Northern blotting. RNA prepared from cultured ECs $\left(10^{8}\right.$ cells $)$ using the guanidinium thiocyanate procedure (23) was applied to agarose-formaldehyde gels $(0.8 \% ; 30 \mu \mathrm{g})$, and transferred to nylon filters. Filters were prehybridized for $1 \mathrm{~h}$ at $68^{\circ} \mathrm{C}$ with QUIK Hyb buffer 
(Stratagene, La Jolla, CA) and hybridized in QUIK Hyb buffer for $3 \mathrm{~h}$ at $68^{\circ} \mathrm{C}$ in the presence of ${ }^{32} \mathrm{P}$-labeled full-length human VCAM- $1 \mathrm{cDNA}$ (24) labeled by the random primer procedure. Filters were then washed with SSC $(2 \times)$ containing SDS $(0.1 \%)$ twice for 15 min each at room temperature, washed again with SSC $(0.1 \times)$ containing SDS $(0.1 \%)$ for $30 \mathrm{~min}$ at $55^{\circ} \mathrm{C}$, dried and subjected to autoradiography. To assess RNA loading, filters were also hybridized with random primer labeled ${ }^{32} \mathrm{P}-\mathrm{cDNA}$ for glyceraldehyde phosphate dehydrogenase (GAPDH) using the same washing and hybridization procedure.

Nuclear run-on transcription assay. Nuclear run-on transcription assay was performed using a modification of the methods as described by Santisteban et al. (25). ECs were incubated with AGE albumin (100 $\mu \mathrm{g} / \mathrm{ml})$ or native albumin $(100 \mu \mathrm{g} / \mathrm{ml})$ for $6 \mathrm{~h}$ at $37^{\circ} \mathrm{C}$. Monolayers were then washed twice with cold phosphate-buffered saline, scraped, and cell pellets prepared. Pellets were then resuspended in $10 \mathrm{ml}$ of lysis buffer containing Tris $(0.01 \mathrm{M}, \mathrm{pH} 7.4), \mathrm{NaCl}(10 \mathrm{mM}), \mathrm{MgCl}_{2}$ ( $3 \mathrm{mM})$, Nonidet P-40 (0.5\% [ vol/vol ]), leupeptin $(50 \mu \mathrm{g} / \mathrm{ml})$, dithiothreitol $(1 \mathrm{mM})$, phenylmethylsulfonyl fluoride $(0.5 \mathrm{mM})$, and aproti$\operatorname{nin}(100 \mu \mathrm{g} / \mathrm{ml})$, incubated for $15 \mathrm{~min}$ on ice, and centrifuged at 500 $g$ for $5 \mathrm{~min}$ at $4^{\circ} \mathrm{C}$. The nuclear pellets were washed once with lysis buffer as above $(4 \mathrm{ml})$ and centrifuged at $500 \mathrm{~g}$ for $5 \mathrm{~min}$ at $4^{\circ} \mathrm{C}$ Supernatants were discarded and nuclei resuspended in $0.2 \mathrm{ml}$ reaction buffer containing Tris ( $10 \mathrm{mM}, \mathrm{pH} 8.0), \mathrm{MgCl}_{2}(5 \mathrm{mM}), \mathrm{KCl}(300$ $\mathrm{mM})$, dithiothreitol ( $1 \mathrm{mM}), \operatorname{ATP}(0.5 \mathrm{mM}), \mathrm{CTP}(0.5 \mathrm{mM}), \mathrm{GTP}(0.5$ $\mathrm{mM})$, and $200 \mathrm{microcurie}$ of $\left[\alpha-{ }^{32} \mathrm{P}\right] \mathrm{UTP}(3,000 \mathrm{Ci} / \mathrm{mmol}$; Amersham, Arlington Heights, IL), and reacted at $30^{\circ} \mathrm{C}$ for $1 \mathrm{~h}$. RNA was extracted as above and samples resuspended in hybridization buffer containing PIPES ( $50 \mathrm{mM}, \mathrm{pH} 6.8)$, EDTA (10 mM), $\mathrm{NaCl}(600 \mathrm{mM})$, SDS $(0.2 \%)$, and denatured salmon test DNA $(100 \mu \mathrm{g} / \mathrm{ml})$. Hybridization to denatured human VCAM-1 and $\beta$-actin DNA slot-blotted on nylon filters was performed at $42^{\circ} \mathrm{C}$ for $72 \mathrm{~h}$ after prehybridization at $80^{\circ} \mathrm{C}$ for $2 \mathrm{~h}$ in hybridization buffer as above containing $0.1 \%$ SDS. After hybridization, the filters were washed in SSC $(2 \times)$ containing SDS $(0.1 \%)$ for $1 \mathrm{~h}$ three times, briefly air-dried and exposed to autoradiographic film for $4 \mathrm{~d}$. For binding to the nylon filter, the human VCAM gene DNA and $\beta$-actin gene DNA were denatured by incubation with $\mathrm{NaOH}(0.3 \mathrm{~N})$ for $30 \mathrm{~min}$ at $65^{\circ} \mathrm{C}$. DNA was spotted onto the nylon filter and cross-linked with a UV cross-linker (Stratagene).

Electrophoretic mobility shift assays (EMSA). Nuclear extracts were prepared from ECs by the method of Schreiber et al. (26). Protein concentration was determined using the Bradford reagent as above. Double-stranded oligonucleotides representing a portion of the human VCAM-1 promoter containing an NF-kB site or a mutant NF-kB site were synthesized (GenSet, Paris, France) (24). Oligonucleotides were used as probes as follows: NF-kB: 5'CCTTGAAGGGATTTCCCTCC 3 ' and a mutated, inactive form 5'CCTTGAATTTATTTAAATCC3' (24). Probes were 5' end-labeled with $\gamma-\left[{ }^{32} \mathrm{P}\right]$ ATP and polynucleotide kinase. Each reaction contained $10 \mathrm{fmol}$ of probe and 2-5 $\mu \mathrm{l}(1.5 \mu \mathrm{g}$ protein) of nuclear extract. Binding reactions were performed in HEPES $50 \mathrm{mM}$ ( $\mathrm{pH} 7.9)$, glycerol (5\%), $\mathrm{KCl}(5 \mathrm{mM})$, $\mathrm{MgCl}_{2}$, dithiothreitol ( $1 \mathrm{mM}$ ), and poly (dI-dC; $1 \mu \mathrm{g}$ ) in a reaction volume of $20 \mu \mathrm{l}$ for $20 \mathrm{~min}$ at room temperature. Complexes were resolved on nondenaturing polyacrylamide gels $(6 \%)$ in Tris $(50 \mathrm{mM})$ borate $(45 \mathrm{mM})$, and EDTA $(0.5 \mathrm{mM}),(0.5 \times$ TBE buffer; final $\mathrm{pH}$ 7.5). Samples were subjected to electrophoresis for $2 \mathrm{~h}$ at $10 \mathrm{~V} / \mathrm{cm}$, gels were then dried and subjected to autoradiography. For supershift assays, complexes were preincubated for $2 \mathrm{~h}$ at $4^{\circ} \mathrm{C}$ with $7.5 \mu \mathrm{g} / \mathrm{ml}$ of anti-p65 IgG, anti-p50 IgG (Santa Cruz Biotechnology, Santa Cruz CA), both together, or nonimmune IgG, in a total reaction volume of $20 \mu \mathrm{l}$.

Immunostaining. Immunostaining for VCAM-1 was performed on lung tissue which had been placed in freezing medium (Polysciences, Inc., Warrington, PA) and snap frozen in dry ice/methanol for sectioning. Sections were incubated in blocking buffer (phosphate-buffered saline/bovine serum albumin $[1 \%] /$ normal rabbit serum [4\%]), and then exposed for $45 \mathrm{~min}$ at $37^{\circ} \mathrm{C}$ to monoclonal rat anti-murine VCAM$1 \mathrm{IgG}$ ( $20 \mu \mathrm{g} / \mathrm{ml}$; Southern Biotechnologies, Birmingham, AL). Pri- mary antibody was revealed with rabbit anti-rat Extra Avidin (Sigma Chemical Co.) using acetylethylcarbazole as the chromogen.

\section{Results}

Exposure of cultured human ECs to AGEs increases their adhesivity for Molt-4 cells and expression of VCAM-1. EC monolayers incubated with AGE albumin exhibited time-dependent enhancement of Molt-4 binding (these cells bear the counter ligand for VCAM-1, very late antigen 4 (VLA-4; 22); which was maximal at $2 \mathrm{~h}$ (Fig. $1 \mathrm{~A}$ ) and gradually fell to the baseline by $12 \mathrm{~h}$ (data not shown). AGE-enhanced binding of Molt-4 cells to endothelium was prevented by blocking with $\mathrm{F}\left(\mathrm{ab}^{\prime}\right)_{2}$ against VCAM-1, suggesting a central role for VCAM-1 as the $\mathrm{EC}$ adherence molecule mediating this interaction (Fig. $1 \mathrm{~B}$ ). De novo endothelial protein synthesis was required to support Molt-4 binding, as preincubation of endothelium with cycloheximide was inhibitory (Fig. $1 B$ ). Molt-4 binding to AGE-treated ECs was not due to passive adsorption of the glycated protein to the endothelial surface because affinity-purified antibody to AGEs, which prevents their cellular interactions $(18,19)$, had no effect when added during the adherence assay (data not shown).

In parallel with increased VCAM-1-dependent binding of Molt-4 cells to AGE-treated endothelium, expression of VCAM- 1 antigen by ECs was enhanced as measured by ELISA (Fig. $2 A$ ); this occurred in a time-dependent manner similar to that observed for Molt-4 binding to AGE-treated endothelium (data not shown). Enhancement of cellular VCAM-1 expression by AGEs was prevented by addition of cycloheximide (Fig. $2 A$ ), consistent with results of cell adherence experiments (Fig. $1 B$ ). AGEs obtained from diabetic serum (18) also enhanced EC expression of VCAM-1 (Fig. $2 A$ ), indicating that AGEadducts generated in vivo had similar properties, with respect to endothelial VCAM-1 expression, compared to AGE albumin prepared in vitro. In contrast, AGE-depleted serum was without effect (Fig. $2 A$ ). The effect of AGEs on VCAM-1 expression was selective, as there was no change in EC levels of ICAM1 as measured by ELISA after treatment with AGE albumin (Fig. $2 B$ ), whereas tumor necrosis factor- $\alpha$, added as a positive control, significantly increased ICAM-1 expression (27). Human aortic vein endothelial cells were also tested for their response to AGEs since they more closely approximate the endothelial cells likely to be relevantly affected in in vivo models of atherosclerosis. When human aortic endothelial cells were exposed to AGE albumin, expression of cellular VCAM-1 antigen was increased as measured by ELISA (Fig. $2 C$ ) whereas native albumin was without effect (Fig. 2 C).

Consistent with possible AGE-induced de novo synthesis of VCAM-1, levels of VCAM-1 mRNA were elevated in ECs exposed to AGE albumin, whereas transcripts for GAPDH were unchanged (Fig. $2 D$ ). Nuclear run-on transcription assay indicated that this was due to increased transcription of mRNA for VCAM-1 in AGE-treated ECs (Fig. 2 E).

Mechanisms underlying AGE-induced EC expression of $V C A M-1$. Previous studies have shown that RAGE is present in ECs, both in vitro and in vivo, and that it is the principal binding site on endothelium for AGEs (11). To determine if AGE-RAGE interaction-mediated VCAM-1 induction, access to RAGE was blocked with monospecific antibody to RAGE, and with sRAGE, the latter a truncated form of full-length 

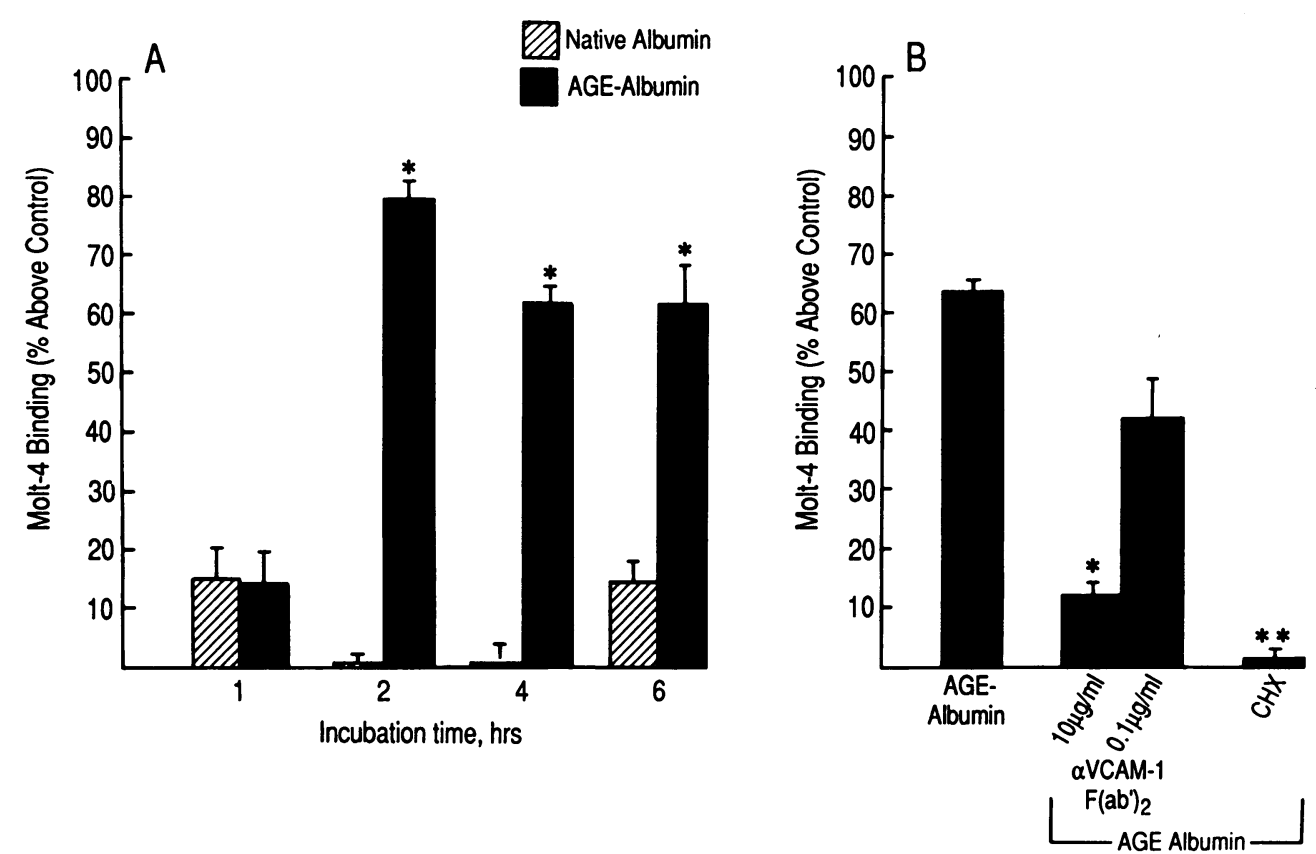

Figure 1. Exposure of ECs to AGE albumin enhances their adhesivity for Molt-4 cells. $(A)$ ECs were incubated for the indicated times with AGE albumin ( $100 \mu \mathrm{g}$ / $\mathrm{ml})$ or nonglycated albumin $(100$ $\mu \mathrm{g} / \mathrm{ml}$ ) at $37^{\circ} \mathrm{C}$ as shown, washed, and then a binding assay was performed with ${ }^{51} \mathrm{Cr}$-labeled Molt-4 cells. $(B)$ ECs were incubated with AGE albumin $(100 \mu \mathrm{g} / \mathrm{ml})$, washed, and then a Molt- 4 binding assay was performed. Where indicated, ECs were pretreated with anti-VCAM-1 $\mathrm{F}\left(\mathrm{ab}^{\prime}\right)_{2}$ for $30 \mathrm{~min}$ immediately before the Molt- 4 binding assay; or the endothelium was pretreated with cycloheximide ( $50 \mu \mathrm{g} / \mathrm{ml}$ for $1 \mathrm{~h}$ ) before exposure to AGE albumin. In each case, the mean \pm SEM of at least triplicate determinations is shown. In $A$, * denotes $P<0.01$ compared with native albumin using the student's unpaired $t$ test. In $B$, $*$ and ** denote $P<0.01$ and $P$ $<0.001$, respectively, compared with treatment with AGE albumin alone using the student's unpaired $t$ test.
RAGE comprising the extracellular domain (11-13). Pre-incubation of ECs with anti-RAGE $\mathrm{F}\left(\mathrm{ab}^{\prime}\right)_{2}$ largely prevented AGEmediated increased endothelial adherence of Molt-4 cells (Fig. $3 A$ ) and anti-RAGE IgG blocked the increase in VCAM-1 antigen completely (Fig. $3 B$ ), whereas nonimmune reagents had no effect (Fig. 3, $A$ and $B$ ). sRAGE had a similar, though even more complete $(>95 \%)$ inhibitory effect on the binding of Molt-4 cells to AGE-treated ECs and their expression of VCAM-1 (Fig. 3, $A$ and $B$ ). These data indicated that AGERAGE interaction had a central role in AGE induction of endothelial VCAM-1.

AGEs tethered to cell surface RAGE induce cellular oxidant stress; this assertion is based on several lines of evidence, including generation of thiobarbituric acid-reactive substances, expression of heme oxygenase type I mRNA, and activation of the transcription factor NF-kB (19). NF-kB sites in the VCAM1 promoter have been shown to participate in regulation of VCAM-1 expression in response to cytokines, mediated, at least in part, by an oxidant mechanism impacting on activation of NF-kB $(20,24,28)$. These data led us to examine if AGEinduced cellular oxidant stress was involved in up-regulating VCAM-1 expression. Pretreatment of endothelium with the antioxidant $N$-acetylcysteine inhibited AGE-enhanced Molt-4 binding (Fig. $3 A$ ) as well as enhanced expression of VCAM1 antigen (Fig. $3 B$ ). In addition, AGE binding to endothelial RAGE triggered events resulting in expression of DNA binding activity for the NF-kB site in the VCAM-1 promoter. Activation of NF-kB, by incubating the ECs with TNF- $\alpha$, served as a positive control in this experiment (Fig. $3 C$, lane 1). After exposure of ECs to AGE albumin, EMSA demonstrated a gel shift band (Fig. $3 C$, lanes 3, 6, and 10) not observed with cultures exposed to native albumin (Fig. $3 C$, lane 2). AGEinduced DNA binding activity was sequence specific, as its appearance was blocked by excess unlabelled NF-kB probe, but was not affected by a mutationally inactivated NF-kB probe (Fig. $3 C$, lanes 4 and 5, respectively). DNA binding activity was probably dependent on p50 and p65 proteins of the NF-kB family in the nucleus, as indicated by the distinct retardation patterns of AGE-induced gel shift bands in the presence of antip65 IgG (Fig. $3 C$, lane 7), anti-p50 IgG (Fig. $3 C$, lane 8 ) or in the presence of both antibodies (Fig. $3 C$, lane 9), suggesting the involvement of both the p50 and p65 proteins of the NF$\mathrm{kB}$ family. The same concentration of nonimmune $\operatorname{IgG}$ was without effect (data not shown). NF-kB activation was largely inhibited by the higher concentration of anti-RAGE IgG, 70 $\mu \mathrm{g} / \mathrm{ml}$ (Fig. $3 C$, lane 11 ) whereas a lower concentration of anti-RAGE IgG, $0.7 \mu \mathrm{g} / \mathrm{ml}$ had no effect (Fig. $3 C$, lane 12). In contrast, nonimmune IgG did not alter intensity of the AGEinduced gel shift band (Fig. $3 C$, lane 13). NF-kB activation by AGE albumin was also inhibited by addition of $N$-acetylcysteine (Fig. $3 C$, lane 14). These data indicate that AGE binding to endothelial RAGE activates nuclear binding activity for the VCAM-1 NF-kB site, likely via an oxidant mechanism. Consistent with these data, elevated levels of VCAM-1 transcripts in AGE-treated ECs were blocked in the presence of anti-RAGE IgG, but not with nonimmune IgG (Fig. $3 \mathrm{D}$, lanes 2 and 3, respectively), and by $N$-acetylcysteine (data not shown).

Infusion of AGEs induces VCAM-1 in mice and patients with diabetes display increased expression of soluble VCAM1. In view of the association of AGEs and oxidant stress with diabetes (8), we considered whether induction of VCAM-1 might occur in diabetic vasculature. To approach this question, 
A

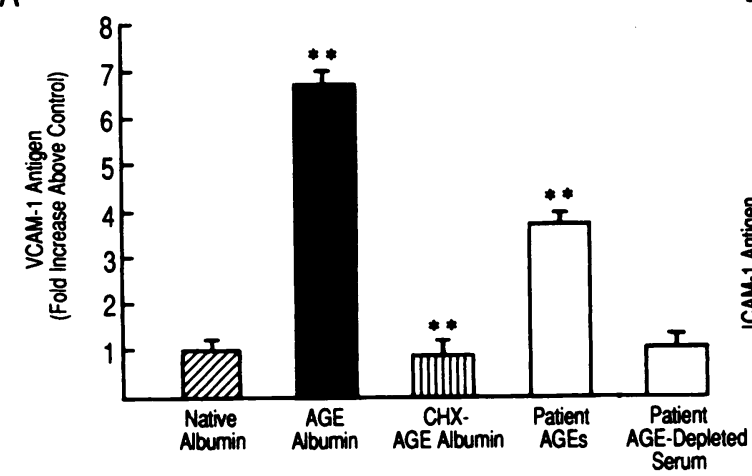

D

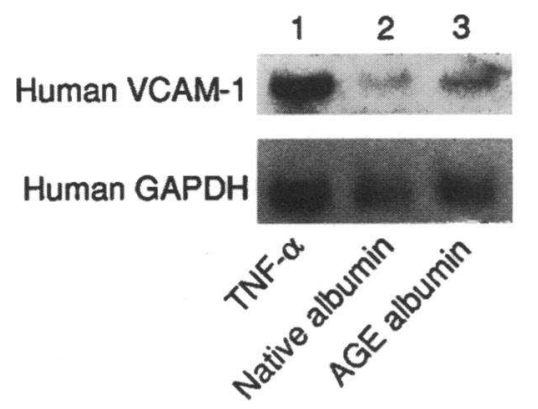

B

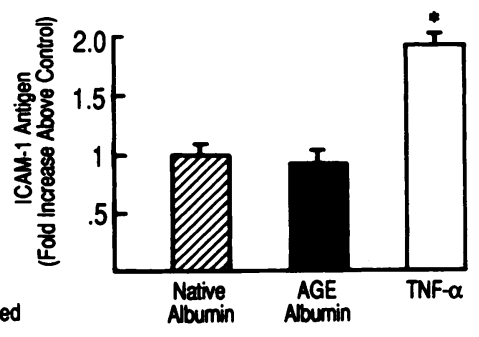

C

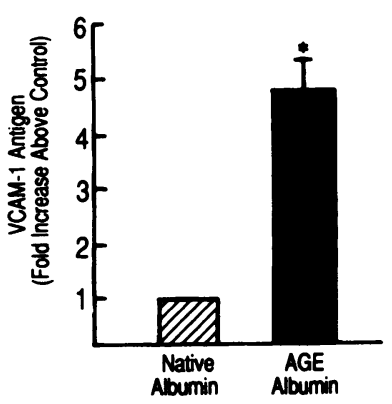

$E$

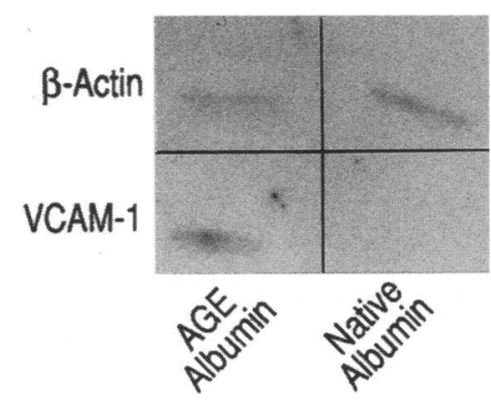

Figure 2. Effect of AGE Albumin and AGEs from diabetic plasma on EC expression of VCAM-1. $(A)$ ECs (human umbilical vein) were incubated for $6 \mathrm{~h}$ with AGE albumin $(100 \mu \mathrm{g} / \mathrm{ml})$, native, nonglycated albu$\min (100 \mu \mathrm{g} / \mathrm{ml})$, patient-derived AGEs $(10 \mu \mathrm{g} / \mathrm{ml})$ or patient AGE-depleted serum (this material represented the pass-through from the anti-AGE IgG Affigel 10 resin, thus equivalent volumes to that of patient-derived AGEs were added to each culture well) at $37^{\circ} \mathrm{C}$, and then cell-associated ELISA for VCAM-1 antigen was performed. Where indicated, cycloheximide (CHX; 50 $\mu \mathrm{g} / \mathrm{ml}$ for $1 \mathrm{~h}$ ) was added prior to EC treatment with AGE albumin. The mean \pm SEM of at least triplicate determinations is shown. ** above AGE albumin and patient AGEs denotes $P<0.001$ compared to native albumin using the student's unpaired $t$ test, and ** above CHX-AGE albumin denotes $P<0.001$ compared with treatment with AGE albumin alone using the student's unpaired $t$ test. (B) ECs (human umbilical vein) were incubated for $6 \mathrm{~h}$ at $37^{\circ} \mathrm{C}$ with AGE albumin $(100 \mu \mathrm{g} / \mathrm{ml})$ or native albumin $(100 \mu \mathrm{g} / \mathrm{ml})$ and cellular ELISA for ICAM-1 antigen was performed. As indicated, TNF $(10 \mathrm{nM})$ was incubated for $6 \mathrm{~h}$ at $37^{\circ} \mathrm{C}$ with ECs as a positive control. The mean \pm SEM of at least triplicate determinations is shown. ${ }^{*}$ denotes $P<0.01$ compared with native albumin alone using the student's unpaired $t$ test. $(C)$ Human aortic endothelial cells were incubated for $6 \mathrm{~h}$ with AGE albumin $(100 \mu \mathrm{g} / \mathrm{ml})$ or native, nonglycated albumin at $37^{\circ} \mathrm{C}$, and then cell-associated ELISA for VCAM-1 antigen was performed. The mean \pm SEM of at least triplicate determinations is shown. ** above AGE albumin indicates $P<0.001$ compared to native albumin using the student's unpaired $t$ test. $(D)$ Northern analysis of EC RNA for VCAM-1 transcripts: effect of AGE albumin. ECs were incubated with TNF- $\alpha$ (10 nM) (lane 1) or native nonglycated albumin (100 $\mu \mathrm{g} / \mathrm{ml}$ ) (lane 2) or AGE albumin $\left(100 \mu \mathrm{g} / \mathrm{ml}\right.$ ) (lane 3) as indicated for $6 \mathrm{~h}$ at $37^{\circ} \mathrm{C}$, RNA was harvested, subjected to electrophoresis, blotted onto nitrocellulose and hybridization with ${ }^{32}$ P-labeled cDNA probes for VCAM-1 or GAPDH performed as indicated. $(E)$ Nuclear run-on transcription assay: ECs were treated with AGE albumin $(100 \mu \mathrm{g} / \mathrm{ml})$ or native albumin $(100 \mu \mathrm{g} / \mathrm{ml})$ for $6 \mathrm{~h}$ at $37^{\circ} \mathrm{C}$, nuclei isolated and ${ }^{32} \mathrm{P}-$ labeled nuclear run on products hybridized to denatured human VCAM-1 gene DNA or $\beta$-actin gene DNA slot-blotted on nylon filters, as described above.

AGE albumin was infused into normal mice and expression of VCAM-1 in the vasculature was assessed. After administration of AGE albumin, VCAM-1 was identified in murine vasculature by immunostaining (Fig. $4 \mathrm{~B}$ ), but was absent in animals infused with native albumin (Fig. $4 A$ ).

These data led us to inquire whether patients with diabetes might also exhibit increased expression of VCAM-1. In pilot studies, incubation of AGE albumin with ECs not only led to increased cell-associated VCAM-1 (Fig. $2 \mathrm{~A}$ ), but also to increased soluble(s) VCAM-1 in culture supernatants based on ELISA (Fig. $4 C$ ); elaboration of sVCAM-1 occurred in a timedependent manner parallelling expression of cellular VCAM (data not shown). Of note, pilot studies revealed that EC supernatants containing sVCAM-1 did not antagonize binding of Molt-4 cells to stimulated ECs expressing VCAM-1 (data not shown). These data suggested that sVCAM-1 might serve as a marker for AGE-induced (and probably the capacity of other mediators to induce) VCAM-1 expression. SVCAM-1 antigen was measured in patients with a spectrum of diabetic complications at different stages in the severity of their vascular disease
(Fig. $4 D$ ). Only patients with diminished glomerular filtration rate were excluded, as SVCAM-1 levels have been shown to be elevated with renal insufficiency (29). Patients with diabetes $(n=18)$ displayed sVCAM-1 levels (mean, $1,115 \mathrm{ng} / \mathrm{ml}$ ) $\sim 1.8$-fold higher than that observed in age-matched nondiabetic controls (mean, $632 \mathrm{ng} / \mathrm{ml})(n=20 ; P<0.001$ using the student's unpaired $t$ test). Consistent with these data, diabetic patients demonstrated higher circulating levels of plasma AGEs as measured by ELISA ( $244 \mathrm{ng} / \mathrm{ml}$ AGE albumin equivalents) than age-matched controls (157 ng/ml AGE albumin equivalents, $P<0.001$ using the student's unpaired $t$ test).

\section{Discussion}

Our results indicate that AGEs, aldose-modified proteins present within the intravascular space and which accumulate in the vessel wall and other tissues especially in diabetes (7-10), interact with endothelium to induce VCAM-1, an adhesion molecule for MPs associated with development of atherosclerosis (3-6). These data add to a growing body of evidence concern- 
A

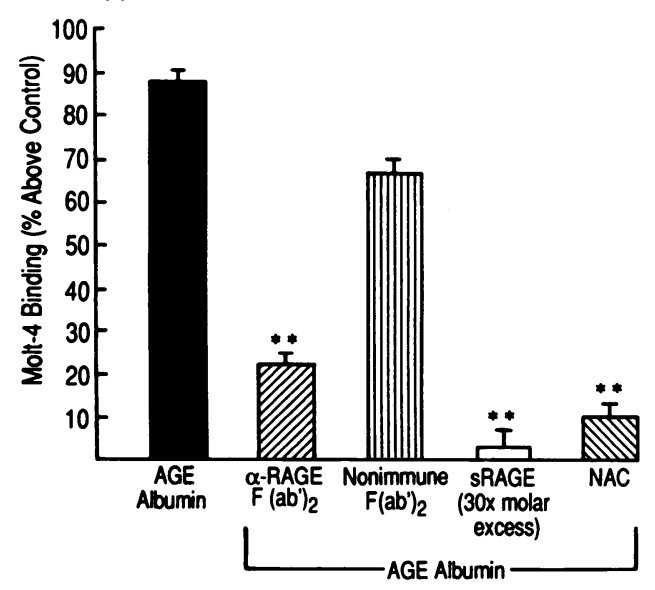

B

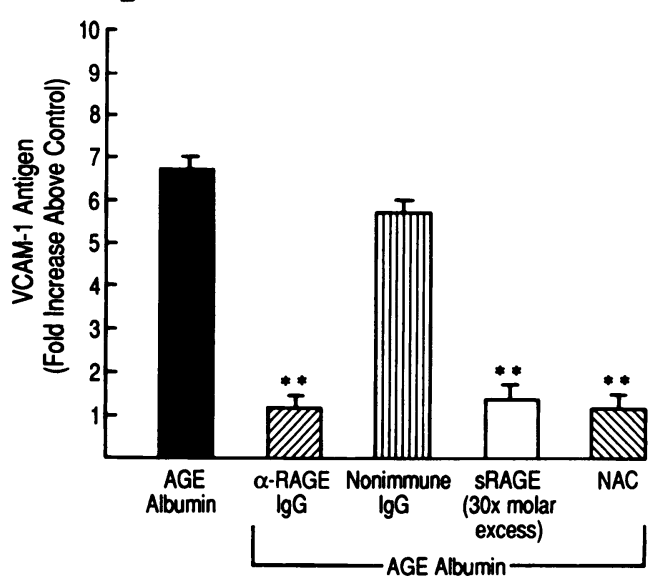

C
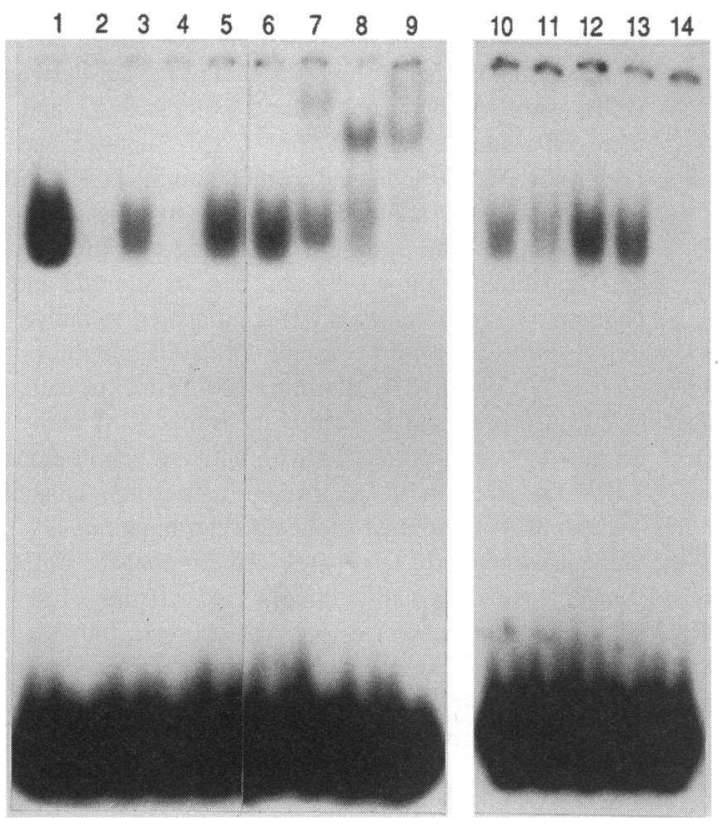
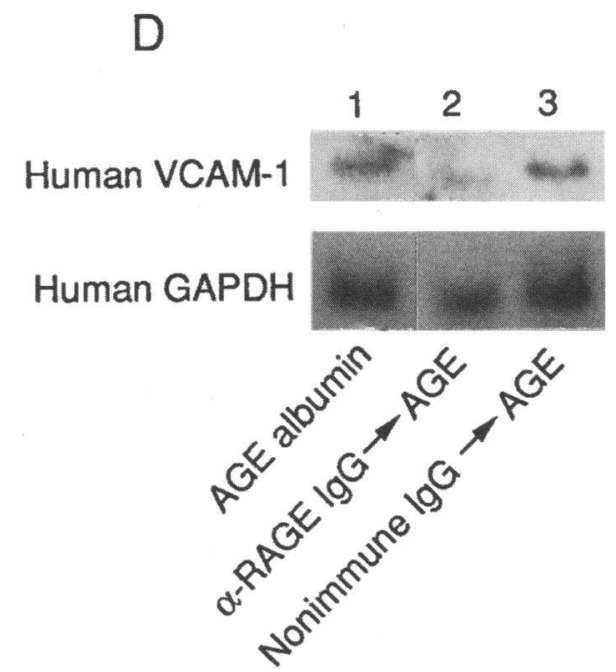

Figure 3. AGE albumin-mediated induction of endothelial VCAM-1: effect of blocking access to RAGE on enhanced Molt-4 binding $(A)$, enhanced expression of VCAM-1 antigen $(B)$, activation of NF-kB $(C)$, and enhanced VCAM-1 transcription $(D)$. (A) ECs were incubated with AGE albumin $(100 \mu \mathrm{g} / \mathrm{ml})$ alone for $6 \mathrm{~h}$ at $37^{\circ} \mathrm{C}$ or in the presence of nonimmune $\mathrm{F}\left(\mathrm{ab}^{\prime}\right)_{2}(2 \mu \mathrm{g} /$ $\mathrm{ml})$, anti-RAGE $\mathrm{F}\left(\mathrm{ab}^{\prime}\right)_{2}(2$ $\mu \mathrm{g} / \mathrm{ml})$, sRAGE ( $1500 \mu \mathrm{g} /$ $\mathrm{ml}$ ) or $N$-acetylcysteine (30 $\mathrm{mM}$ ) as above. A binding assay was then performed with ${ }^{51} \mathrm{Cr}$-labeled Molt-4 cells as described. The mean \pm SEM of at least triplicate determinations is shown. In all cases, ** denotes $P<0.001$ compared with treatment with AGE albumin alone using the student's unpaired $t$ test. ( $B$ ) ECs were incubated with AGE albumin alone or in the presence of anti-RAGE IgG ( $30 \mu \mathrm{g} / \mathrm{ml}$ for $3 \mathrm{~h}$ ), nonimmune IgG ( $30 \mu \mathrm{g} /$ $\mathrm{ml}$ for $3 \mathrm{~h}$ ) or $\mathrm{N}$-acetyl cysteine ( $30 \mathrm{mM}$ for $60 \mathrm{mins}$ ) and cellular ELISA for VCAM-1 was performed. In each case, the mean \pm SEM of at least triplicate determinations is shown. $* *$ denotes $P<0.001$ compared with treatment with AGE albumin alone using the student's unpaired $t$ test. ( $C$ ) Binding of EC nuclear proteins to NF-kB binding site in the VCAM-1 promoter:

EMSA. All lanes contain the labelled probe. Lanes refer to

samples obtained from: ECs incubated for $6 \mathrm{~h}$ at $37^{\circ} \mathrm{C}$ with TNF- $\alpha(10 \mathrm{nM}$, lane 1$)$ nonglycated albumin $(100 \mu \mathrm{g} / \mathrm{ml}$, lane 2$)$ or with AGE albumin $(100 \mu \mathrm{g} / \mathrm{ml}$, lanes 3, 6, and 10); nuclear extract from ECs incubated with AGE albumin preincubated with anti-p50 IgG (lane 8) or anti-p65 IgG (lane 7) or both anti-p50 IgG and anti-p65 IgG together (lane 9). ECs were either preincubated with anti-RAGE IgG (70 $\mu \mathrm{g} / \mathrm{ml}$ or $0.7 \mu \mathrm{g} / \mathrm{ml}$ for $3 \mathrm{~h}$, lanes 11 and 12 , respectively) or nonimmune $\operatorname{IgG}(70 \mu \mathrm{g} / \mathrm{ml}$ for $3 \mathrm{~h}$, lane 13$)$ or $N$-acetylcysteine (30 mM for $1 \mathrm{~h}$, lane 14), followed by treatment with AGE albumin $(100 \mu \mathrm{g} / \mathrm{ml})$ for $6 \mathrm{~h}$ at $37^{\circ} \mathrm{C}$. After treatment with AGE albumin for $6 \mathrm{~h} \mathrm{at} 37^{\circ} \mathrm{C}$, EC nuclear extracts were prepared and incubated with ${ }^{32} \mathrm{P}$-labeled NF-kB probe in the presence of an 100-fold molar excess of either unlabelled NF-kB (lane 4) or the mutated NF$\mathrm{kB}$ probe (lane 5). (D) ECs were incubated with AGE albumin ( $100 \mu \mathrm{g} / \mathrm{ml}$ ) (lane 1) for $6 \mathrm{~h}$ in the presence or absence of anti-RAGE IgG (30 $\mu \mathrm{g} / \mathrm{ml}$ for $3 \mathrm{~h}$ ) or nonimmune $\mathrm{IgG}(30 \mu \mathrm{g} / \mathrm{ml}$ for $3 \mathrm{~h}$ ) (lanes 2 and 3 , respectively) and then RNA extracted and Northern blotting performed as above.

ing functional consequences of AGE binding to RAGE. These include increased permeability of EC monolayers (30); changes in cell surface coagulant properties with induction of low levels of tissue factor procoagulant activity (30); and receptor-mediated transcytosis and delivery of the glycated ligand to the subendothelium (14) where it permits interaction with smooth muscle cells. AGE-mediated induction of VCAM-1 also elucidates an evolving picture in which the glycated ligand stimulates cytokine and growth factor production, and modulates macrophage migration. There is accelerated chemotaxis of macro- phages in response to a gradient of soluble AGEs and inhibition of migration when a deposit of immobilized AGEs is encountered $(18,31,32)$. Expression of VCAM-1 by ECs in response to AGE albumin probably underlies the enhanced monocyte binding followed by transmigration through EC monolayers grown on filters with AGEs in the lower compartment $(18,31)$. This suggests the possibility that AGEs within the vessel wall (33) could stimulate overlying endothelium to produce VCAM1 , thereby targeting MPs to the vessel surface. Such AGEs, which are present for long times within the vessel wall, might 

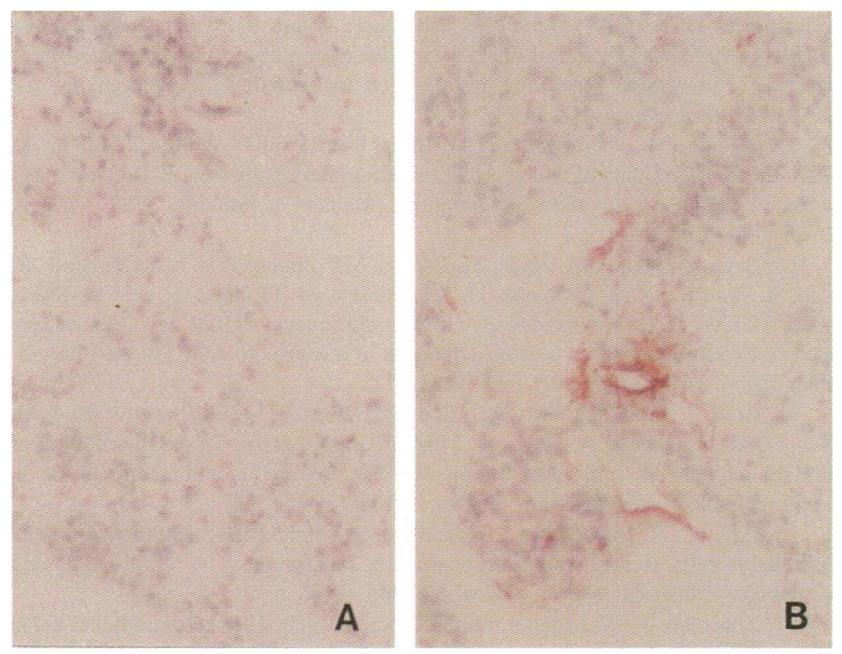

C

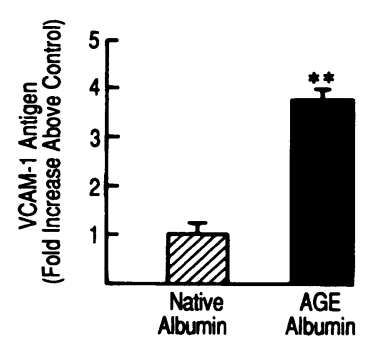

\section{D}

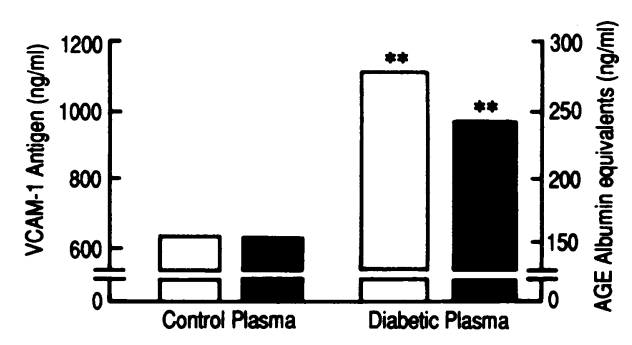

Figure 4. AGE albumin infusion induces vascular expression of VCAM-1 $(A$ and $B)$, release of sVCAM-1 from cultured ECs $(C)$, and SVCAM-1 is present in diabetic plasma $(D) .(A-B)$ Mice were infused with either nonglycated albumin $(500 \mu \mathrm{g} /$ animal; $A)$ or AGE albumin $(500 \mu \mathrm{g} /$ animal; $B)$ and $6 \mathrm{~h}$ later lung was harvested and immunostaining with anti-murine VCAM-1 antibody was performed. Magnification: $\times 340$. $(C)$ ECs were incubated with AGE albumin $(100$ $\mu \mathrm{g} / \mathrm{ml})$ or nonglycated albumin $(100 \mu \mathrm{g} / \mathrm{ml})$ for $6 \mathrm{~h}$ at $37^{\circ} \mathrm{C}$, culture supernatant was collected, concentrated 10-fold, and assayed for VCAM-1 antigen by ELISA. The mean \pm SEM of at least triplicate determinations is shown. ${ }^{* *}$ denotes $P<0.001$ using the student's unpaired $t$ test. $(D)$ Plasma from patients with diabetes ( $n$ $=18$ ) or normal controls $(n=20)$ was obtained and assayed for VCAM-1 antigen or AGE albumin equivalent by ELISA. For sVCAM-1, values are $1,115 \mathrm{ng} / \mathrm{ml}$ $(\mathrm{SD}=469 \mathrm{ng} / \mathrm{ml})$ for diabetic patients and $632 \mathrm{ng} / \mathrm{ml}$ $(\mathrm{SD}=115 \mathrm{ng} / \mathrm{ml})$ for age-matched controls. For AGE levels, values are $244 \mathrm{ng} / \mathrm{ml}$ AGE albumin equivalents ( $\mathrm{SD}=27 \mathrm{ng} / \mathrm{ml}$ AGE albumin equivalents) for diabetic patients and $157 \mathrm{ng} / \mathrm{ml}$ AGE albumin equivalents (54 $=\mathrm{ng} / \mathrm{ml}$ AGE albumin equivalents). In both cases, ** denotes $P<0.001$ using the student's unpaired $t$ test. have a more sustained effect on EC expression of VCAM-1 and/or could magnify effects of other stimuli which modulate endothelial VCAM-1 production, such as cytokines (27). Thus, measurement of circulating (plasma) AGE levels may only be partially relevant given the likely diffuse distribution of pathogenic irreversibly-glycated proteins in the vasculature, only some of which may be readily amenable to isolation and analysis pre-mortem.

Although AGEs comprise a class of heterogeneous structures, their interactions with endothelium appear to be mediated mostly via RAGE (11-12). In the current studies, either blocking antibody/F $\left(\mathrm{ab}^{\prime}\right)_{2}$ or sRAGE inhibited induction of VCAM-1 at the same concentrations that blocked binding of AGE albumin to the EC surface. Interaction of AGE albumin with MPs, as well as their interaction with other AGE-modified proteins (34), has been shown similarly to involve RAGE, suggesting that this receptor is a major site for cell surface AGE-mediated events although other AGE cellular binding sites may also be present $(35,36)$. VCAM-1 expression appears to be induced by generation of cellular oxidant stress consequent on cell surface AGE-RAGE interaction. This could arise from ROIs produced by the glycated proteins themselves $(8,37-$ 40 ) and/or receptor-mediated triggering of signal transduction mechanisms leading to low levels of oxygen-free radical production $(20,24,41-43)$. Specific signal transduction mechanisms activated by AGE-RAGE interaction have not been mapped in detail, but based on the presence of a short, highly charged cytosolic tail at the receptor carboxy terminus, we hy- pothesize that ligand-receptor interaction allows the cytosolic tail to bind intracellular polypeptides which participate in signaling. These observations support the concept that RAGE is not a simple scavenger receptor which rapidly endocytoses and degrades AGEs, thereby clearing tissues of aldose-modified polypeptides or lipids; rather, engagement of the ligand sets in motion events which lead to a spectrum of changes in cellular properties. In view of the potentially injurious nature of subsequent cellular events following AGE-RAGE interaction, it seems probable that AGEs are accidental ligands of RAGE, a receptor meant to recognize other ligands in quite different settings. Such a role for RAGE other than binding to AGEs is supported by evidence of enhanced RAGE expression in the central nervous system in early development and in some types of mature neurons, and its strong constitutive expression in smooth muscle cells (15; data not shown).

The observation that the AGE-RAGE interaction induces cell-associated VCAM-1, and also releases SVCAM-1 antigen into culture supernatants, suggests a means of monitoring this event in vivo. Furthermore, increased levels of sVCAM-1 were observed in diabetic patients compared with a range of normal controls. Although the functional significance of SVCAM-1 is at present unclear (pilot studies have shown lack of antagonism of Molt-4 binding to EC surface VCAM-1), sVCAM-1 could serve as a marker of vascular perturbation in diabetes. Since endothelial expression of VCAM-1 occurs in response to diverse stimuli, including cytokines (27), and could result from the oxidant stress consequent on hyperglycemia itself (44), 
plasma VCAM-1 levels are likely to reflect the complexity of events which occur within the vasculature in vivo. Even with these diverse stimuli for induction of VCAM-1 in diabetes, we hypothesize that serial sVCAM-1 levels could be of benefit in identifying patients at high risk for the development of clinically apparent vascular complications (as a result of EC perturbation due to AGEs or other agents) and might provide a surrogate marker for assessment of therapy designed to attenuate the progression of vascular disease.

Taken together with our recent demonstration that AGEs induce expression by smooth muscle cells of the chemotactic polypeptide JE/MCP-1 (45), these data suggest a pathway through which AGEs attract monocytes to bind to the vessel surface, followed by their migration into the vessel wall and subsequent stimulation with production of mediators potentially contributing to the development of vascular lesions. The recent observation of increased VCAM-1 expression in diabetic rabbits (5) and our finding of elevated SVCAM-1 levels in diabetic patient plasma suggests that this cell adherence molecule might have a important role in the pathogenesis of diabetic vascular disease.

\section{Acknowledgments}

We are grateful for the advice of Dr. Gabriel Godman throughout the course of these studies. The authors gratefully acknowledge the excellent technical support of Rebecca A. Moss and Luis Ferran.

This work was supported by grants from the United States Public Health Service (AG-00602, HL-21006, HL-42833, HL-42507, HL50629), American Heart Association-New York affiliate, Juvenile Diabetes Foundation, and Council for Tobacco Research.

\section{References}

1. Krolewski, A., J. Warram, P. Valsania, B. Martin, L. Laffel, and A. Christlieb. 1991. Evolving natural history of coronary artery disease in diabetes mellitus. Am. J. Med. 90:56S-61S.

2. Factor, S., B. Segal, and K. van Hoeven. 1992. Diabetes and coronary vascular disease. Coron. Art. Dis. 3:4-10.

3. Cybulsky, M., and M. Gimbrone. 1991. Endothelial expression of a mononuclear leukocyte adhesion molecule during atherogenesis. Science (Wash. DC). 251:788-791.

4. Li, H., M. Cybulsky, M. Gimbrone, and P. Libby. 1993. An atherogenic diet rapidly induces VCAM-1, a cytokine-regulatable mononuclear leukocyte adhesion molecule, in rabbit aortic endothelium. Arterioscler. Thromb. 13:197-204.

5. Richardson, M., S. Hadcock, M. DeReske, and M. Cybulsky. 1994. Increased expression in vivo of VCAM-1 and E-selectin by the aortic endothelium of normolipemic and hyperlipemic diabetic rabbits. Arterioscler. Thromb. 14:760769.

6. O'Brien, K. D., M. D. Allen, T. O. McDonald, A. Chait, J. M. Harlan, D. Fishbein, J. McCarty, M. Ferguson, K. Hudkins, C. D. Benjamin, R. Lobb, and C. E. Alpers. 1993. Vascular cell adhesion molecule-1 is expressed in human coronary atherosclerotic plaques. Implications for the mode of progression of advanced coronary atherosclerosis. J. Clin. Invest. 92:945-951.

7. Ruderman, N., J. Williamson, and M. Brownlee. 1992. Glucose and diabetic vascular disease. FASEB (Fed. Am. Soc. Exp. Biol.) J. 6:2905-2914.

8. Baynes, J. 1992. Role of oxidative stress in development of complications in diabetes. Diabetes. 40:405-412.

9. Sell, D., and V. Monnier. 1989. Structure elucidation of a senescence crosslink from human extracellular matrix: implication of pentoses in the aging process. J. Biol. Chem. 264:21597-21602.

10. Brownlee, M., A. Cerami, and H. Vlassara. 1988. Advanced glycosylation endproducts in tissue and the biochemical basis of diabetic complications. $N$. Engl. J. Med. 318:1315-1320.

11. Schmidt, A-M., O. Hori, J. Brett, S-D. Yan, J-L. Wautier, and D. Stern. 1994. Cellular receptors for advanced glycation endproducts. Arterioscler. Thromb. 14:1521-1528.

12. Schmidt, A-M., M. Vianna, M. Gerlach, J. Brett, J. Ryan, J. Kao, C.
Esposito, H. Hegarty, W. Hurley, M. Clauss, F. Wang, Y-C. Pan, T. Tsang, and D. Stern. 1992. Isolation and characterization of binding proteins for advanced glycation endproducts from lung tissue which are present on the endothelial cell surface. J. Biol. Chem. 267:14987-14997.

13. Neeper, M., A-M. Schmidt, J. Brett, S-D. Yan, F. Wang, Y-C. Pan, K. Elliston, D. Stern, and A. Shaw. 1992. Cloning and expression of RAGE: a cell surface receptor for advanced glycation endproducts of proteins. J. Biol. Chem. 267:14998-15004.

14. Schmidt, A-M., M. Haus, D. Popov, J-H. Zhang, S-D. Yan, J. Brett, R. Cao, K. Kuwabara, G. Costache, N. Simionescu, M. Simionescu, and D. Stern. 1994. The receptor for advanced glycation endproducts (AGEs) has a central role in vessel wall interaction and gene activation in response to AGEs in the intravascular space. PNAS (USA). 91:8807-8811.

15. Brett, J., A-M Schmidt, Y-S. Zou, S-D. Yan, E. Weidman, D. Pinsky, M. Neeper, M. Przysiecki, A. Shaw, A. Migheli, and D. Stern. Tissue distribution of RAGE: expression in smooth muscle, cardiac myocytes, and neural tissue in addition to the vasculature. Am. J. Pathol. 143:1699-1712.

16. Jaffe, E., R. Nachman, C. Becker, and R. Minick. 1973. Culture of human endothelial cells derived from umbilical veins. Identification by morphologic and immunologic criteria. J. Clin. Invest. 52:2745-2756.

17. Thornton, S., S. Mueller, and E. Levine. 1983. Human endothelial cells: use of heparin in long term cloning and serial cultivation. Science (Wash. DC). 222:623-625.

18. Schmidt, A-M., S-D. Yan, J. Brett, R. Mora, R. Nowygrod, and D. Stern. 1993. Regulation of mononuclear phagocyte migration by cell surface binding proteins for AGEs. J. Clin. Invest. 92:2155-2168.

19. Yan, S-D., A-M. Schmidt, M. Anderson, J. Zhang, J. Brett, Y-S. Zou, D. Pinsky, and D. Stern. 1994. Enhanced cellular oxidant stress by the interaction of AGEs with their receptors/binding proteins. J. Biol. Chem. 269:9889-9897.

20. Marui, N., M. Offermann, R. Swerlick, C. Kunsch, C. Raosen, M. Ahmad, R. Alexander, and R. Medford. 1993. VCAM-1 gene transcription and expression are regulated through an oxidant-sensitive mechanism in human vascular endothelial cells. J. Clin. Invest. 92:1866-1874.

21. Sasseville, V., W. Newman, A. Lackner, M. Smith, N. Lausen, D. Beall, and D. Ringler. 1992. Elevated vascular cell adhesion molecule-1 in AIDS encephalitis induced by simian immunodeficiency virus. Am. J. Pathol. 141:1021-1030.

22. Carlos, T., B. Schwartz, N. Kovach, E. Yee, M. Rosso, L. Osbron, R. Chi, B. Newman, R. Lobb, and J. Harlan. 1990. VCAM-1 mediates lymphocyte adherence to cytokine-activated cultured human endothelial cells. Blood. 76:965970.

23. Chirgwin, J., A. Przbyla, R. MacDonald, and W. Rutter. 1979. Isolation of biologically active ribonucleic acids from sources enriched in ribonuclease. Biochemistry. 18:5294-5299.

24. Neish, A., A. Williams, H. Palmer, M. Whitley, and T. Collins. 1992. Functional analysis of the human VCAM-1 promoter. J. Exp. Med. 176:15831593.

25. Santisteban, P., L. D. Kohn, and R. DiLauro. 1987. Thyroglobulin gene expression is required by insulin and insulin-like growth factor-1, as well as thyrotropin, in FRTL5 thyroid cells. J. Biol. Chem. 262:4048-4052.

26. Schrieber, E., P. Matthias, M. Muller, and W. Schaffner. 1989. Rapid detection of octamer binding proteins with "mini-extracts," prepared from a small number of cells. Nucleic Acids Res. 17:6419.

27. Pober, J., and R. Cotran. 1990. Cytokines and endothelial cell biology. Physiol. Revs. 70:427-451.

28. Iademarco, M., J. McQuillan, and D. Dean. 1993. VCAM-1: contrasting transcriptional control mechanisms in muscle and endothelium. PNAS (USA). 90:3943-3947.

29. Gearing, A. J., I. Hemingway, R. Piggot, J. Hughes, A. J. Rees, and S. J. Cashman. 1992. Soluble forms of vascular adhesion molecules, E-selectin, ICAM1, and VCAM-1: pathological significance. Ann. NY Acad. of Sci. 667:324-31.

30. Esposito, C., H. Gerlach, J. Brett, D. Stern, and H. Vlassara. 1989. Endothelial receptor-mediated binding of glucose-modified albumin is associated with increased monolayer permeability and modulation of cell surface coagulant properties. J. Exp. Med. 170:1387-1407.

31. Kirstein, M., J. Brett, S. Radoff, D. Stern, and H. Vlassara. 1990. AGEs induce selective monocyte migration across endothelium, and elaboration of growth factors. PNAS (USA). 87:9010-9014.

32. Vlassara, H., M. Brownlee, K. Manogue, C. Dinarello, and A. Pasagian. 1988. Cachectin/TNF and IL-1 induced by glucose-modified proteins: role in normal tissue remodeling. Science (Wash DC). 240:1546-1548.

33. Nakamura, Y., Y. Horii, T. Nishino, H. Shiiki, Y. Sakaguchi, T. Kagoshima, K. Dohi, Z. Makita, H. Vlassara, and R. Bucala. 1993. Immunohistochemical localization of AGEs in coronary atheroma and cardiac tissue in diabetes mellitus. Am. J. Pathol. 143:1649-1656.

34. Schmidt, A. M., O. Hori, S. D. Yan, S. Ogawa, D. Stern, and T. Miyata. 1994. The mononuclear phagocyte interaction site of $\beta_{2}$-microglobulin modified by glycation is RAGE. Cir. 90:I-233 (\#1251) Abstract.

35. Yang, Z., Z. Makita, Y. Horii, S. Brunelle, A. Cerami, P. Sehajpal, M. 
Suthanthiran, and H. Vlassara. 1991. Two novel rat liver membrane proteins that bind AGEs: relationship to macrophage receptor for glucose-modified proteins. J. Exp. Med. 174:515-524.

36. Kodama, T., M. Freeman, L. Rohrer, J. Zabrecky, P. Matsudaira, and M. Krieger. 1990. Type I macrophage scavenger receptor contain helical and collagen-like coiled coils. Nature (Lond.). 343:531-535.

37. Hicks, M., I. Delbridge, D. Yue, and R. Reeve. 1988. Catalysis of lipid peroxidation by glucose and glycosylated proteins. Biochem. Biophys. Res. Commun. 151:649-655.

38. Hunt, J., C. Smith, and S. Wolff. 1990. Autooxidative glycosylation and possible involvement of peroxides and free radicals in LDL modification by glucose. Diabetes. 30:1420-1424.

39. Mullarkey, C., D. Edelstein, and M. Brownlee. 1990. Free radical generation by early glycation products: a mechanism for accelerated atherogenesis in diabetes. Biochem. Biophys. Res. Commun. 173:932-939.
40. Sakurai, T., and S. Tsuchiya. 1988. Superoxide production from nonenzymatically glycated protein. FEBS Lett. 236:406-410.

41. Schreck, R., and P. Baeuerle. 1991. A role for oxygen radicals as second messengers. Trends Cell Biol. 1:39-42.

42. Schreck, R., P. Rieber, and P. Baeuerle. 1991. Reactive oxygen intermediates as apparently widely used messengers in the activation of the NF-kB transcription factor and HIV-1. EMBO (Eur. Mol. Biol. Organ.) J. 10L2247-2258.

43. Collins, T. 1993. Endothelial nuclear factor $\mathrm{kB}$ and the initiation of the atherosclerotic lesion. Lab Invest. 68:499-508.

44. Tesfamariam, B. and R. Cohen. 1992. Free radicals mediate endothelial cell dysfunction caused by elevated glucose. Am. J. Physiol. 263:H321-H326.

45. Friedman, J., R. Pauly, D. Stern, A-M. Schmidt, R. Monticone, and M. Crow. 1994. AGEs activate the expression of monocyte and smooth muscle cell chemoattractants by vascular smooth muscle cells. Circ. 90:I-290 (\#1567, abstract). 